ppi $201502 Z U 4645$

Esta publicación científica en formato digital es continuidad de la revista impresa ISSN-Versión Impresa 0798-1406 / ISSN-Versión on line 2542-3185Depósito legal pp $197402 Z$ U34
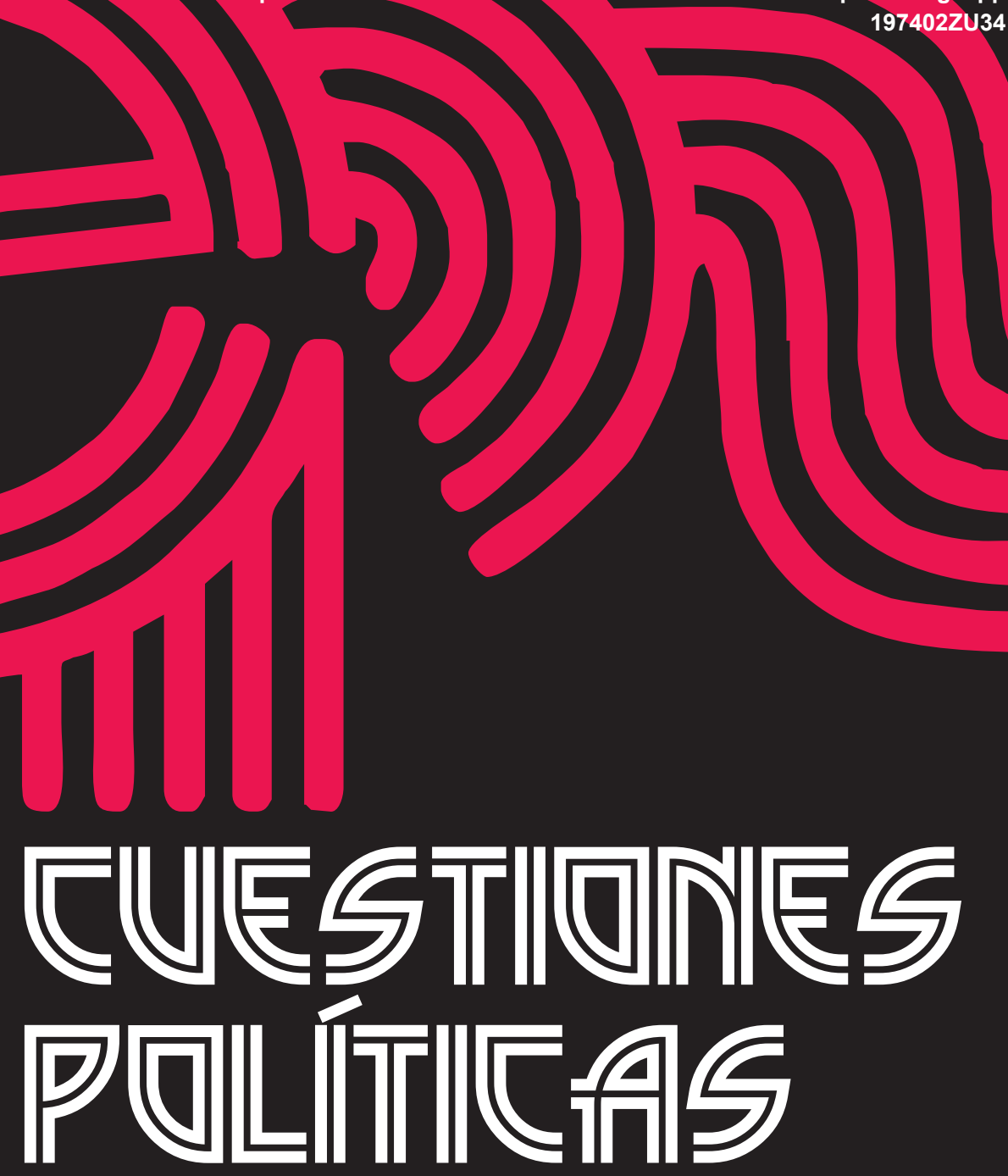

Instituto de Estudios Políticos y Derecho Público "Dr. Humberto J. La Roche" de la Facultad de Ciencias Jurídicas y Políticas de la Universidad del Zulia Maracaibo, Venezuela
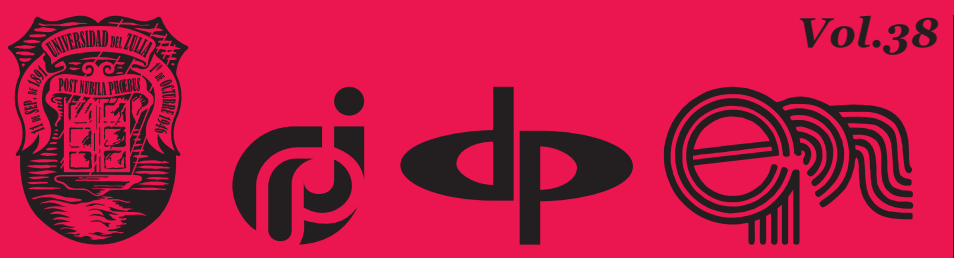

$N^{\circ}$ Especial 2da Parte 2020 


\title{
Special features of vocational training institutions in the context of pandemics
}

\author{
DOI: https://doi.org/10.46398/cuestpol.382e.o6
}

\author{
Elena M. Chertakova * \\ Anna V. Lapshova ** \\ Natalia V. Bystrova *** \\ Zhanna V.Smirnova $* * * *$ \\ Marina N. Bulaeva $* * * * *$
}

\section{Abstract}

The coronavirus pandemic has had a profound impact on society. Educational institutions are taking steps to organize the learning process, which will not only preserve, but also improve its quality in the current critical situation. The purpose of the article is to analyze the experience of implementing distance education in the context of the coronavirus pandemic. The distance learning conditions created to guarantee epidemiological safety in order to preserve the health of students and teachers include the use of innovative technological means. We have proposed several solutions to the problems that have arisen in the process of organizing distance education: organizational problems on the technical side of the subject, reducing the burden of teachers and students, organizing effective independent work, and others. It is concluded that the distance learning media and technologies used in the teaching of professional disciplines contribute to the gradual development of the students' professional competence. The results of the study showed that distance education technologies implemented in the practice of a higher education institution expand the possibilities for students to master educational material.

* Togliatti State University, Togliatti, Russia. ORCID ID: http://orcid.org/oooo-0oo2-2923-5669. Email: hem@tltsu.ru

** Minin Nizhny Novgorod State Pedagogical University, Nizhny Novgorod, Russia. ORCID ID: http:// orcid.org/oooo-ooo1-7017-3589. Email: any19.10@mail.ru

*** Minin Nizhny Novgorod State Pedagogical University, Nizhny Novgorod, Russia, ORCID ID: https:// orcid.org/oooo-0002-4310-6142. Email: bystrova_nv@mail.ru

***** Minin Nizhny Novgorod State Pedagogical University, Nizhny Novgorod, Russia. ORCID ID: http:// orcid.org/oooo-0001-9950-9824. Email: z.v.smirnova@mininuniver.ru

******Minin Nizhny Novgorod State Pedagogical University, Nizhny Novgorod, Russia. ORCID ID: http:// orcid.org/oooo-0oo2-9928-9451. Email: bulaevamarina@mail.ru 
Keywords: new coronavirus pandemic; long distance education; vocational education; video conferencing; vocational training.

\section{Características especiales de las instituciones de formación profesional en el contexto de pandemias}

\section{Resumen}

La pandemia de coronavirus ha tenido un impacto profundo en la sociedad. Las instituciones educativas están tomando medidas para organizar el proceso de aprendizaje, lo que no solo preservará, sino que también mejorará su calidad en la crítica situación actual. El propósito del artículo es analizar la experiencia de implementar la educación a distancia en el contexto de la pandemia de coronavirus. Las condiciones de aprendizaje a distancia creadas para garantizar la seguridad epidemiológica en aras de preservar la salud de estudiantes y docentes incluyen el uso de medios tecnológicos innovadores. Hemos propuesto varias soluciones a los problemas que han surgido en el proceso de organización de la educación a distancia: problemas de organización del lado técnico del tema, reducción de la carga de profesores y estudiantes, organización del trabajo independiente eficaz, y otros. Se concluye que, los medios y tecnologías de aprendizaje a distancia utilizados en la enseñanza de disciplinas profesionales contribuyen al desarrollo gradual de la competencia profesional de los estudiantes. Los resultados del estudio mostraron que las tecnologías de educación a distancia implementadas en la práctica de una institución de educación superior amplían las posibilidades de que los estudiantes dominen el material educativo.

Palabras clave: pandemia del nuevo coronavirus; educación a distancia; educación vocacional; videoconferencia; formación profesional.

\section{Introduction}

The spread of coronavirus infection affected all spheres of society, including education. Restrictions related to quarantine measures led to changes in the learning process. The paramount task in a pandemic is the adoption of adequate measures to support the subjects of vocational education, contributing to the preservation and improvement of its quality 
(Tsarapkina et al., 2019a). In the current critical situation, the relevance of the implementation of remote sensing technologies sharply increases (Arbeláez-Campillo and Villasmil Espinoza, 2020). At a time when online learning is becoming the only opportunity to implement the educational process, consistent, promptly made decisions are important to enable professional educational institutions to carry out their activities.

The level of technological equipment of educational institutions and the preparation of teachers for the implementation of distance learning is one of the challenges of the crisis (Pichugina and Bondarchuk, 2019). The success of the implementation of distance education depends, among other things, on the ability to maintain active communication between students and teachers (Klinkov, 2018). In Russia, long before the outbreak of the COVID-19 virus, following the innovative development, measures were provided for the implementation of the distance educational process. According to the Federal Law "On Education in the Russian Federation" dated December 29, 2012 No. 273-FZ, the implementation of educational programs should be carried out using various educational technologies, including distance educational technologies, e-learning.

The procedure for the use of e-learning, distance learning technologies by organizations carrying out educational activities in the implementation of educational programs, approved by order of the Ministry of Education and Science of the Russian Federation No. 816 dated August 23, 2017, means that organizations must create conditions for the functioning of electronic information and educational environment, which will ensure that students master educational programs in full and regardless of their location. The document also stated that educational organizations can implement educational programs using exclusively distance technologies. Most of the implemented educational programs of higher education providers for the use of distance technologies in the process of educational activities (Vaskovskaya, 2018). And today, when in the current epidemiological situation, the use of online courses and distance technologies is an urgent need, Russian educational institutions are successfully implementing them in the preparation of students (Chertovskikh, 2019). However, during a pandemic, the load on distance learning systems and teachers increases significantly, the type of interaction between the subjects of the educational process changes (Filchenkova, 2019). The full transition to online classes leads to the emergence of specific features of training. There is a need to identify these features and the impact of distance learning on the quality of student training. 


\section{Theoretical framework}

The coronavirus has become a global challenge for vocational education. Given the seriousness of the reasons for the transformation of the educational process and the prospects for its development in the existing conditions, this research topic in the current situation requires special attention. The features of the activities of educational institutions during the spread of coronavirus infection were reflected in the works of A.A. (Akhmetshin, 2020). The adaptation of vocational education to the "new reality" causes difficulties, since the remote form of work does not allow to fully implement the practical side of education. Many researchers draw attention to this issue as the most important in training students during a pandemic (Pliushch, 2018).

Scientists offered recommendations for organizing the activities of educational institutions in remote conditions during the COVID-19 period. These include: maintaining a balance between e-learning and activities outside the e-office; introduce open educational resources into use, develop new electronic educational platforms and courses; develop international cooperation to exchange educational online resources.

The issues of implementation of remote technologies are disclosed by S.G. Grigoriev (Grigoriev et al., 2019), O. Yu. Donetskova (Donetskova, 2019) and others. Features of the organization of the educational process are distinguished by G.M. Birzhenyuk (Birzhenyuk et al., 2020), T.V. Efimova, T.E. Davydova (Davydova, 2020), A.S. Tishchenko (Tishchenko, 2020) and others. Among the characteristic features of distance learning are: flexibility of training (each student can choose a convenient time for him to complete tasks) (Ivanov et al., 2020); modularity (the study of the discipline is carried out in blocks); the advisory role of the teacher and some others (Tsarapkina et al., 2019b).

In the context of the spread of coronavirus, the ability of students to educate themselves and self-organize is of particular importance, since a significant amount of materials are intended for independent study (Ponachugin and Lapygin, 2019). The questions of self-organization are revealed in his works by A.A. Andrienko (Andrienko, 2019a), (Andrienko, $2019 \mathrm{~b}$ ). The discipline during the online learning period contributes to achieving the best results without the direct supervision of the teacher (Cirdan, 2019). 
Elena M. Chertakova, Anna V. Lapshova, Natalia V. Bystrova, Zhanna V. Smirnova y Marina N. Bulaeva

\section{Methodology}

We have proposed several solutions to problems that have arisen in the process of organizing distance learning: issues of organizing the technical side of the issue, reducing the load on teachers and students, organizing effective independent work, and others. The existing requirements for conducting distance learning turned out to be ineffective, so there is a need for research in this area. We took into account the work carried out by experts in the field of distance education during the pandemic in 2020. The study involved 352 graduate students of three Russian higher educational institutions. We analyzed the summary sheets for professional disciplines for 2019 and exam results in 2020. Professional exam results in 2019 (before the pandemic) were compared with student learning outcomes in 2020 (after distance learning).

A survey was also conducted among students studying in a distance format, aimed at improving online learning. A fragment of the questionnaire is presented in Table 1 .

\begin{tabular}{|c|l|l|}
\hline No. & \multicolumn{1}{|c|}{ Question } & Answer \\
\hline 1 & $\begin{array}{l}\text { Was it easy to concentrate on the educational process } \\
\text { during the distance learning period? }\end{array}$ & $\begin{array}{l}- \text { Yes } \\
- \text { No }\end{array}$ \\
\hline 2 & Were there any difficulties in mastering the material? & $\begin{array}{l}\text {-Yes } \\
\text {-No }\end{array}$ \\
\hline 3 & $\begin{array}{l}\text { What are the main reasons for the difficulties in } \\
\text { mastering the material? }\end{array}$ & $\begin{array}{l}\text { Free } \\
\text { answer }\end{array}$ \\
\hline 4 & $\begin{array}{l}\text { What would you highlight the main advantages of the } \\
\text { distance learning format? }\end{array}$ & $\begin{array}{l}\text { Free } \\
\text { answer }\end{array}$ \\
\hline
\end{tabular}

Table No. 1. Fragment of the survey of the students' opinion of graduate groups on the features of organizing distance learning during the coronavirus period (within the framework of our study)

\section{Results and discussion}

The learning process during the pandemic was built based on various technological solutions, including an electronic educational platform (Petrichev et al., 2018). In Russia, this is a fairly common practice that has been implemented by universities for several years and remains relevant 
today. The main burden for performing tasks during the quarantine period was assigned to the technological capabilities of LMS Moodle (Eliseeva et al., 2020). Students carried out tests, essays, tests, projects and many other types of assignments using this platform. Also, teachers delivered content to students' e-mails (Oros, 2018).

To maintain the attentiveness of students and relieve the load, teachers used a frequent change of activities (every 15-20 minutes). During online classes, students could listen not only to the teacher, but also to each other, discuss topics, take part in a survey, take various tests, divide into groups and complete tasks in a team. Among the new electronic solutions, it is worth mentioning the Zoom service, which was actively involved in preparing students during the spread of the coronavirus. Its capabilities made it possible to organize the interaction of all participants in the educational process and ensure the involvement of all students in the educational process. Students completed assignments both synchronously (at a given moment) and asynchronously (performing assignments at a convenient time). Execution of case tasks is an example of a synchronous mode of operation. Students collectively discuss possible solutions in Zoom's virtual classroom. The combination of synchronous and asynchronous modes makes it possible to intensify the activity of students by changing their types. The asynchronous mode includes texts, video and audio that line up in a coherent course.

To conduct distance classes, tools such as Microsoft Teams and Webinar were used, which made it possible to conduct webinars and video conferencing. Students remotely conducted presentations of their works, participated in trainings with teachers from other cities. The instructors have also made it possible for students to use Coursera courses.

Note that the use of distance technologies is a fairly widespread practice in the university. Throughout the entire period of preparation of students, a blended learning format was used, so graduate students were adapted to the online format. The research participants were students of the 4th year of study. We analyzed the summary sheets for professional disciplines for 2019 and exam results in 2020. Professional exam results in 2019 (before the pandemic) were compared with student learning outcomes in 2020 (after distance learning).

Figure 1 shows the learning outcomes of $4^{\text {th }}$-year students in 2019 and 2020 in professional disciplines. 
Elena M. Chertakova, Anna V. Lapshova, Natalia V. Bystrova, Zhanna V. Smirnova y Marina N. Bulaeva

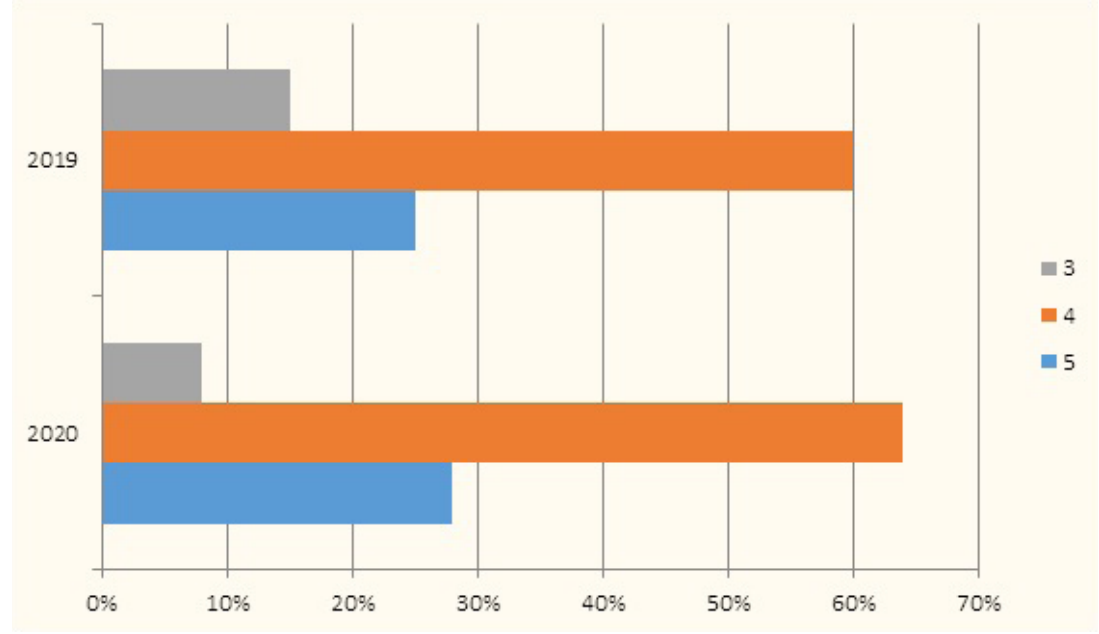

Fig. 1. Statistical analysis of the learning outcomes of graduate

\section{students in professional disciplines (as part of our research)}

The learning outcomes in the professional disciplines taught in the 4th year reflect the good preparation of the students. However, we note that in 2020 , in the context of a pandemic, training was carried out in a distance format and differed from 2019 in the complete absence of face-to-face studies and consultations with a teacher. As you can see from the chart, the numbers for 2020 are higher than those for 2019. The percentage of students with positive ratings has grown. That is, the organization of the learning process using distance learning technologies allows you to maintain and improve the quality of education (Kalinkina and Gorodetskaya, 2017).

A survey was conducted for students who completed the online training, which made it possible to identify the shortcomings of the implementation of distance learning during a pandemic to improve it.

A fragment of the survey results is shown in Figure 2. 


\begin{tabular}{|c|c|c|}
\hline No. & Question & Answer \\
\hline 1 & $\begin{array}{l}\text { Was it easy to concentrate } \\
\text { on the educational process } \\
\text { during the distance } \\
\text { learning period? }\end{array}$ & $\begin{array}{l}-Y e s-65 \% \\
- \text { No }-35 \%\end{array}$ \\
\hline 2 & $\begin{array}{l}\text { Were there any difficulties } \\
\text { in mastering the material? }\end{array}$ & $\begin{array}{l}- \text {-Yes }-83 \% \\
-\mathrm{No}-17 \%\end{array}$ \\
\hline 3 & $\begin{array}{l}\text { What are the main reasons } \\
\text { for the difficulties in } \\
\text { mastering the material? }\end{array}$ & $\begin{array}{l}\text { - growth of educational load - } 69 \% \text {; } \\
\text { - technical shortcomings } \\
\text { of electronic equipment - } 35 \% \text {; } \\
\text { - lack of live communication - } 89 \% \text {; } \\
\text { - irregularity of the work / rest } \\
\text { mode - 50\% }\end{array}$ \\
\hline 4 & $\begin{array}{l}\text { What would you highlight } \\
\text { the main advantages of the } \\
\text { distance learning format? }\end{array}$ & $\begin{array}{l}\text { - free access to educational } \\
\text { materials - } 95 \% \text {; } \\
\text { - the opportunity to receive } \\
\text { individual advice from a teacher at } \\
\text { a convenient time } 88 \% \text {; } \\
\text { - Obtaining automatic test results } \\
\text { for prompt reflection and filling in } \\
\text { deficiencies - } 86 \% \text {; } \\
\text { - flexibility of the educational } \\
\text { process - } 58 \% \text {; } \\
\text { - time-saving - } 45 \%\end{array}$ \\
\hline
\end{tabular}

Table 2. Results of a study of the opinions of graduate students on the specifics of organizing distance learning during the coronavirus period (within the framework of our study)

The most common answers among students were selected for the table. In the context of an epidemiological situation, students note that it was quite easy to concentrate on the educational process and the lack of face-to-face studies did not affect their mastering of the material. It is also worth noting that the period of distance learning nevertheless caused some difficulties, which are associated with an increase in workload, peculiarities of technical equipment, and non-observance of the work and rest regime. Also, students note the lack of live communication. However, this fact, given the spread of coronavirus infection, largely reflects the effect of self-isolation. Among the main advantages, students highlighted free access to educational materials (up-to-date information when completing assignments is always open to students), the ability to receive individual advice from a teacher at 
Elena M. Chertakova, Anna V. Lapshova, Natalia V. Bystrova, Zhanna V. Smirnova y Marina N. Bulaeva

a convenient time, receive automatic test results for prompt reflection and fill deficiencies, the flexibility of the educational process and time saving ...

For a holistic assessment of the distance educational process, students were asked to answer the question "How would you assess the level of organization of the distance educational process in a pandemic?"

The results are shown in Figure 2.

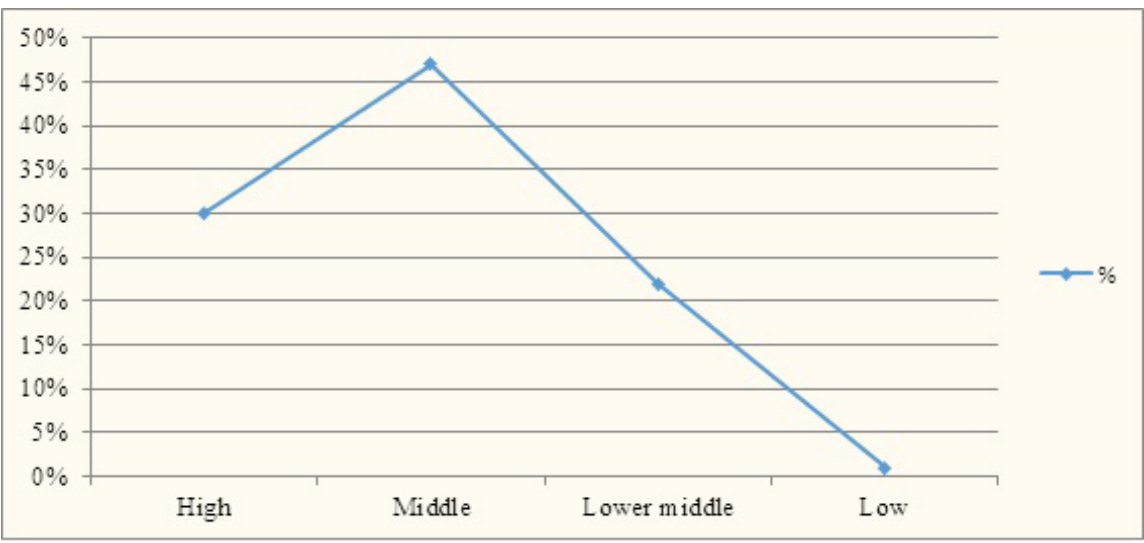

Fig. 2. Analysis of the results of students' assessment of the organization of distance learning during the COVID-19 pandemic (as part of our research)

Most students assess the level of organization of the educational process in the context of the spread of coronavirus infection as average (47\%). $30 \%$ of respondents note a high level. 22\% of students rate the level as "below average". The educational process in remote conditions today requires thorough revision. His organization in 2020 faced many challenges amid the pandemic. In a situation of urgent need to transfer students to an electronic educational environment, issues related to the insufficient information competence of teachers, the technical capabilities of the computer equipment of teachers and students, the speed and quality of the Internet, the rules for conducting classes and other issues have become aggravated. More students are forced to independently master the educational material. It becomes difficult to sort out difficult moments, since the load on teachers has increased dramatically and they cannot always provide advice to students. Many students find it difficult to organize their education in an electronic environment without the direct participation of a teacher. 


\section{Conclusions}

The article analyzed the features of the activities of vocational education institutions in the context of the coronavirus pandemic. Distance learning conditions created to ensure epidemiological safety in the interests of preserving the health of students and teachers include the use of innovative technology means that ensure effective remote interaction.

The study showed that distance educational technologies implemented in the practice of a higher educational institution expand the possibilities for students to master educational material, however, in the emergency conditions of the transition to a distance educational process, several difficulties have arisen that have to be overcome. For this, it is necessary to provide teachers with methodological assistance in using electronic resources, eliminate the low quality of open materials, provide prompt technical support, instruct and consult technical specialists, reduce the number of reports on the work done. To soften the conditions for the stay of students and teachers in the virtual space and reduce the load, it is necessary to introduce monitoring of student attendance, alternate independent work and work in virtual conditions, record lectures for re-viewing at a convenient time. The technical side of the issue also needs improvement. Not all students can use the services to participate in webinars. Educational institutions must solve the problem by providing this opportunity for every student.

Despite the challenges posed by the spread of the virus, the implementation of distance education made it possible not only to avoid the termination of the functioning of professional educational institutions and prevent a decline in the quality of the educational process, but also to improve it.

\section{Bibliographic References}

AKHMETSHIN, Airat Adikovich. 2020. "Features of the activities of institutions of additional professional education in the context of the coronavirus pandemic in Russia” In: Innovation and Investment, No. 8, pp. 239-232.

ANDRIENKO, Oksana A. 2019a. "On the need to apply gaming training technologies” In: Balkan Scientific Review. Vol. 2, No 4, pp. 5-8.

ANDRIENKO, Oksana A. 2019b. "Modern educational technologies: technology of self-presentation” In: Balkan Scientific Review. Vol. 1 No. 3, pp. 5-7. 
Elena M. Chertakova, Anna V. Lapshova, Natalia V. Bystrova, Zhanna V. Smirnova y Marina N. Bulaeva

86

Special features of vocational training institutions in the context of pandemics

ARBELÁEZ-CAMPILLO, Diego Felipe., VILLASMIL ESPINOZA, Jorge Jesús. 2020. "Escenarios prospectivos de un nuevo orden internacional que se vislumbra luego de la pandemia COVID-19” In: Revista Telos, No. 22 (3), Pp. 494.

BIRZHENYUK, Grigory Mikhailovich; EFIMOVA, Tatiana Viktorovna. 2020. "Schering as a new landmark in education" In: Innovative development of vocational education. Vol. 2, No. 26, pp. 12-21.

CHERTOVSKIKH, Olga Olegovna. 2019. "Prospects for the use of digital resources in education" In: Baltic Humanitarian Journal. Vol. 8, No. 4 (29), pp. 184-187.

CIRDAN, Alexander Petrovich. 2019. "Innovative technologies of professional training of future economists in the system of continuous education" In: Humanitarian Balkan Research. Vol. 2, No. 4, pp. 27-30.

DAVYDOVA, Tatiana. 2020. "The specifics of the organization of the educational process at the university in non-standard conditions" In: Production organizer. Vol. 28, No. 2, pp. 97-107.

DONETSKOVA, Olga Yurievna. 2019. "Modernization of the modern education system in Russia” In: Baltic Humanitarian Journal. Vol. 8, No. 2 (27), pp. 37-39.

ELISEEVA, Dina YU; FEDOSOV, Alexander YU; AGALTSOVA, Daria V; MNATSAKANYAN, Olga L; KUCHMEZOV, Khamzat, KH. 2020. "The evolution of artificial intelligence and the possibility of its application in cyber games" In: Amazonia Investiga. Vol. 9 No. 28, Pp. 123-129.

FILCHENKOVA, Irina F. 2019. "Educational management of innovative activity of teachers as an object of pedagogical research" In: Vestnik of Minin University. Vol. 7, (4), 3.

GRIGORIEV, Sergey; SHABUNINA, Valentina; TSARAPKINA, Yuliya; DUNAEVA, Natalya. 2019. "Electronic library system as a means of self-development of students of digital generation $\mathrm{Z}$ (on the example of studying the course "Basics of the counselor activity")" In: Scientific and technical libraries. No. 7. Pp. 78-99. 29.

IVANOV, Mikhail Semenovich; PARNIKOVA, Tatyana Alekseevna; Vladimir Petrovich; PETROV, Nikolay Vadimovich. 2020. "The activity approach implementation in the formation of students' general technical competencies" In: Amazonia Investiga. No. 9(26), pp. 205-210.

KALINKINA, Elena Georgievna; GORODETSKAYA, Natalia Ivanovna. 2017. "Development of e-learning and distance learning technologies in the 
process of professional development of teachers" In: Nizhny Novgorod education. No. 1, pp. 131-138.

KLINKOV, Georgi Todorov. 2018. "The specificity of manifestation of pedagogical communication as a special construct” In: Scientific Vector of the Balkans. No. 1, pp. 51-52.

OROS, Ildiko Imriivna. 2018. "The role of international connections in the development of the adult education system" In: Humanitarian Balkan Research. No. 1, pp. 57-59.

PETRICHEV, Petr Vladimirovich; MASYUK, Natalia Nikolaevna; BUSHUEVA, Marina Alexandrovna. 2018. "Method of estimation of the effectiveness of the partnership russian universities with foreign educational organizations" In: Azimut nauchnykh issledovaniy (Azimuth of Scientific Researches: Economics and Management). Vol.7, No. 3 (24), pp. 229232.

PICHUGINA, Galina Antonovna; BONDARCHUK, Anastasia Igorevna. 2019. "Structure of the training case in the organization of the educational process" In: Humanitarian Balkan Research. Vol. 2, No. 4, pp. 5-7.

PLIUSHCH, Valentyna Mykolaivna. 2018. "Independent work of students as a factor of improving education quality" In: Balkan Scientific Review. No. 1, pp. 69-71.

PONACHUGIN, Alexander; LAPYGIN, Yuri Nikolaevich. 2019. "Digital educational resources of the university: design, analysis and expertise" In: Vestnik of Minin University. Vol. 7 (2), 5.

TISHCHENKO, Alexey S. 2020. "Assessment of the losses of educational organizations from a reduction in the volume of additional educational services to the population during a pandemic" In: Economic Development of Russia. Vol. 27, No. 6, pp. 73-79.

TSARAPKINA,JuliaMikhailovna;PETROVA, Marina Mikhailovna;MIRONOV, leksei Gennadievich; MOROZOVA, Irina Mikhailovna; SHUSTOVA, Olga Borisovna. 2019b. "Robotics as a basis for Informatization of education in children's health camp" In: Amazonia Investiga. Vol. 8, No. 20, pp. 115-123.

TSARAPKINA, Julia. M; DUNAEVA, Nataly V; KIREICHEVA, Alevtina M. 2019a. "Application of BYOD technology in education on the example of Lecture Racing mobile application" In: Informatika i obrazovanie Informatics and Education. No. 9 (308), pp. 56-64.

VASKOVSKAYA, Galina Alekseevna. 2018. "Features of implementation of pedagogical technologies of profile training” In: Balkan Scientific Review. No. 1, pp. 76-79. 
Vol.38 NEspecial

Esta revista fue editada en formato digital y publicada en diciembre de 2020, por el Fondo Editorial Serbiluz, Universidad del Zulia. Maracaibo-Venezuela 